\title{
Pengaruh Metode Pembelajaran Examples Non Examples Terhadap Kognitif Siswa Pada Materi Mengenal Penggunaan Uang Sesuai Dengan Kebutuhan
}

\author{
Warkintin $^{1)}$, Bejo $^{2)}$, Verdinandus Veri ${ }^{3)}$ \\ ${ }^{1,2,3)}$ Negara STKIP Persada Khatulistiwa Sintang, Jl. Pertamina-Sengkuang, Sintang \\ 1) E-mail: warkintin_1984@yahoo.co.id
}

\begin{abstract}
Abstrak. Tujuan penelitian untuk mengetahui pengaruh metode Examples Non Examples terhadap kognitif siswa Pada Materi Mengenal Penggunaan Uang Sesuai dengan Kebutuhan di Kelas III Sekolah Dasar Negeri No 47 Sinar Kasih. Metode yang digunakan metode kuantitatif deskriptif. Bentuk penelitian Quasi-Eksperimen. Hasil analisis data observasi guru dengan persentase 100\%, berkriteria baik, sedangkan data observasi siswa dengan persentase rata-rata 86,93\% berkriteria baik. Berdasarkan perhitungan hasil belajar siswa diperoleh nilai rata-rata pretest untuk kelas eksperimen 41,66, serta kelas kontrol 46,85 dan nilai rata-rata posttest untuk kelas eksperimen 77,59, serta kelas kontrol 69,07. Peningkatan Kognitif siswa dihitung dengan rumus Indeks Gains dan didapat nilai 0,62 artinya terdapat peningkatan yang tinggi kognitif siswa setelah menggunakan metode pembelajaran examples non examples. Teknik pengolahan data menggunakan Uji t-dua sampel karena jumlah siswa 27 orang kelas ekperimen dan 27 orang kelas kontrol serta data berdistribusi normal dan homogen. Hasil dari uji hipotesis diperoleh Pada hasil pretest diketahui bahwa nilai thitung adalah 1,7 sedangkan nilai tabel pada $\alpha=5 \%$ dengan $\mathrm{db}\left(\mathrm{N}_{1}+\mathrm{N}_{2}-2=52\right)$ adalah 2,011 . Hal ini berarti nilai $\mathrm{t}_{\text {hitung }}<\mathrm{t}_{\text {tabelyaitu }}-1,7<2,011$ maka Ho diterima yang artinya tidak terdapat perbedaan yang signifikan kognitif siswa antara kelas eksperimen dan kelas kontrol, sedangkan pada hasil posttest diketahui bahwa nilai thitung adalah 2,79 sedangkan nilai tabel pada $\alpha=5 \%$ dengan db $\left(\mathrm{N}_{1}+\mathrm{N}_{2}-2=52\right)$

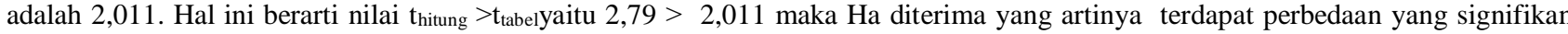
kognitif siswa antara kelas eksperimen dan kelas kontrol. Hasil angket respon siswa dengan rata-rata $88,15 \%$ dengan kriteria sangat kuat.
\end{abstract}

Kata Kunci: Metode Pembelajaran Examples Non Examples dan Kognitif Siswa

\section{PENDAHULUAN}

Pendidikan diartikan sebagai kegiatan pewarisan budaya dari satu generasi kegenerasi yang lain [1]. Perkembangan itu dimulai sejak makhluk hidup tersebut tercipta dan hidup berdampingan dengan makhluk yang lain. Tak terkecuali juga manusia, Piaget membagi tahap-tahap perkembangan kognitif menjadi empat yaitu "tahap sensorimotor (0-2 tahun), tahap praoprasional (2-7/8 tahun), tahap operasional konkret (7/8-11/12 tahun), dan tahap operasional formal (11/12-18 tahun)" [2].

Sejak dilahirkan, manusia tumbuh dan berkembang mulai dari bayi menjadi kanak-kanak dan terjun kedunia pendidikan sampai menjadi dewasa. Interaksi pada anak dalam dunia sekolah diharapkan akan dapat menumbuhkan pengetahuan baru pada anak. Dimana interaksi yang terjadi antara anak dan anak, serta anak dengan guru akan membuat proses belajar dapat berjalan dengan baik dan memiliki keluwesan dalam pelaksanaannya. Keluwesan sangat diperlukan dalam proses belajar mengajar, agar tidak ada jurang pemisah antara murid dengan guru maupun murid dengan murid. Dengan demikian maka akan terciptakan proses belajar yang menyenangkan sehingga membuat anak merasa senang dan memiliki keinginan untuk terus belajar.

Proses pembelajaran timbal balik merupakan proses pembelajaran yang memperlihatkan keaktifan siswa dalam belajar, mengajukan pertanyaan mengenai hal yang belum dimengerti dalam proses pembelajaran. Dengan adanya timbal balik, maka kita dapat melihat dimana kekurangan dan kelebihan yang anak miliki dalam menangkap pembelajaran yang guru sampaikan. Kekurangan pada anak inilah yang nantinya harus diperbaiki dengan metode pembelajaran yang dapat merangkum kemampuan anak dalam menyerap pembelajaran. 
Metode pembelajaran merupakan cara-cara menyajikan materi pembelajaran yang dilakukan oleh pendidik agar terjadi proses belajar pada diri siswa dalam upaya untuk mencapai tujuan, serta berfungsi sebagai pedoman bagi para perancang pembelajaran dan para guru untuk merencanakan dan melaksanakan aktivitas pembelajaran.Untuk itu diperlukan salah satu cara untuk menumbuhkan minat belajar yang dapat meningkatkan hasil belajar siswa dalam menghadapi permasalahan atau menemukan konsep-konsep dari permasalahan yang ada yaitu dengan metode pembelajaran yang cocok dan dapat mengoptimalkan kemampuan siswa dalam menghadapi permasalahan yang ada.

Untuk menentukan suatu metode pembelajaran guru harus dapat memadukan antara materi dan metode pembelajaran agar proses belajar mengajar dapat berjalan sesuai dengan perencanaan. Berdasarkan hasil observasi yang dilakukan pada sekolah yang terletak di Desa Sinar Pekayau, Kecamatan Sepauk, Kabupaten Sintang yaitu Sekolah Dasar Negeri No. 47 Sinar Kasih di kelas III, mata pelajaran IPS pada materi mengenal penggunaan uang sesuai dengan kebutuhan semester genap Tahun Pelajaran 2014/2015, dari 58 siswa terdapat 20 siswa atau $35 \%$ siswa yang nilainya tidak mencapai Kriteria Ketuntasan Minimal (KKM) dengan nilai 65. Faktor utama yang menyebabkan banyak siswa tidak tuntas karena sebagian besar siswa mengalami kesulitan untuk memahami materi mengenal penggunaan uang sesuai dengan kebutuhan.

Salah satu upaya untuk meningkatkan ketertarikan siswa dalam mengikuti pembelajaran khususnya mata pelajaran IPS pada materimengenal penggunaan uang sesuai dengan kebutuhan, adalah dengan menerapkan metode pembelajaran examples non examplesMetode pembelajaran examples non examples merupakan metode pembelajaran dengan mempersiapkan gambar, diagram, atau tabel sesuai dengan materi bahan ajar dan kompetensi, sajian gambar ditempel atau menggunakan OHP, dengan petunjuk gurusiswa mencermati sajian, diskusi kelompok tentang sajian gambar tadi, presentasi hasil kelompok, bimbingan penyimpulan, evaluasi, dan refleksi [3].
Pembelajaran examples non examples ini merupakan metode pembelajaran yang menggunakan gambar sebagai media yang dapat membantu dan mendorong siswa melatih diri dalam mengembangkan pola pikir dalam mengemukakan pendapat maupun ide-ide, dan dapat bermanfaat secara fungsional bagi siswa untuk aktif termotivasi dalam belajar. Metode pembelajaran ini juga lebih didominasi oleh peserta didik, guru sebagai fasilitator serta mengarahkan peserta didik, sehingga siswa memiliki pengalaman yang melekat pada dirinya akan materi mengenal penggunaan uang sesuai dengan kebutuhan yang disesuaikan dengan kehidupan sehari-hari. Berdasarkan uraian tersebut maka peneliti tertarik untuk melakukan penelitian tentang: "Pengaruh Metode Pembelajaran Examples Non Examples Terhadap Kognitif Siswa pada Materi Mengenal Penggunaan Uang Sesuai dengan Kebutuhan Di Kelas III Sekolah Dasar Negeri No. 47 Sinar Kasih".

\section{METODE}

Secara umum metode penelitian diartikan sebagai cara ilmiah untuk mendapatkan data dengan tujuan dan kegunaan tertentu [4]. Pendekatan metode dalam penelitian ini adalah dengan pendekatan kuantitatif. Metode kuantitatif adalah data penelitian berupa angka-angka dan dianalisis menggunakan statistik [5]. Bentuk penelitian dalam penelitian ini adalah Quasieksperimen dengan desain penelitian Nonequivalent Control Group Design. Dalam desain ini diberikan pretest untuk mengetahui kemampuan awal peserta didik sebelum perlakuan diberikan. Setelah diberikan perlakuan, tahap selanjutnya adalah memberikan posttest untuk mengetahui kemampuan peserta didik. Desain dalam penelitian ini dapat dilihat pada tabel 1 .

TABEL 1

RANCANGAN NONEQUIVALENT CONTROL GROUP DESIGN

\begin{tabular}{cccc}
\hline Kelompok & Pretest & Treatment & Posttest \\
\hline Eksperimen & $\mathrm{O}_{1}$ & $\mathrm{X}$ & $\mathrm{O}_{2}$ \\
Kontrol & $\mathrm{O}_{3}$ & & $\mathrm{O}_{4}$ \\
\hline
\end{tabular}


Keterangan:

$\mathrm{O}_{1}=$ Kelompok eksperimen sebelum diberikan perlakuan

$\mathrm{O}_{2}=$ Nilai kelompok eksperimen setelah diberikan perlakuan

$\mathrm{O}_{3}=$ Nilai awal kelompok kontrol

$\mathrm{O}_{4}=$ Nilai akhir kelompok kontrol

$\mathrm{X}=$ Perlakuan menggunakan metode pembelajaran examples non examples

Populasi dalam penelitian ini adalah seluruh siswa kelas III Sekolah Dasar Negeri No. 47 Sinar Kasih , yang berjumlah 54 siswa. Terdiri dari 27 siswa kelas IIIA dan 27 siswa kelas IIIB. Teknik pengambilan sampel dalam penelitian ini adalah teknik Sampling Jenuh. Sampling Jenuh yaitu teknik penentuan sampel bila semua anggota populasi digunakan sebagai sampel [4]. Sampel dalam penelitian ini adalah semua kelas III Sekolah Dasar Negeri no. 47 Sinar Kasih dimana kelas IIIA sebagai kelas eksperimen dan kelas IIIB sebagai kelas control.

\section{HASIL DAN PEMBAHASAN}

Berdasarkan analisis observasi guru pada pertemuan pertama dan kedua, maka didapat hasil persentase pertemuan pertama $100 \%$ dan pertemuan kedua $100 \%$, sehingga didapat hasil persentase pelaksanaan dengan rata-rata $100 \%$ dengan kriteria Baik, artinya guru telah melaksanakan pembelajaran mulai dari pendahuluan sampai penutup pembelajaran dengan baik yaitu sesuai dengan rencana pelaksanaan pembelajaran. Hasil observasi guru selanjutnya dapat dilihat pada Gambar 1.

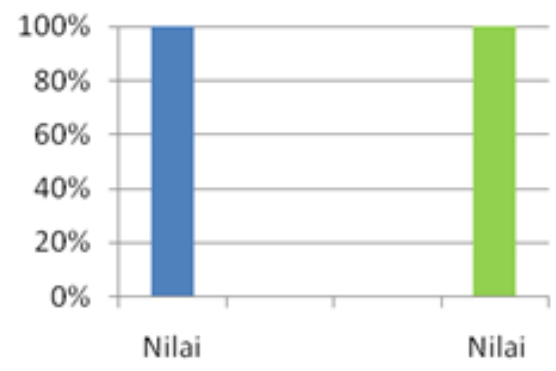

a PERTEMUAN II

- PERTEMUAN I

Gambar 1. Hasil Analisis Lembar Observasi Guru

Berdasarkan hasil observasi siswa yang diamati oleh tiga orang observer dengan jumlah siswa 27 orang, disimpulkan siswa memperhatikan penjelasan materi dengan metode examples non examples yaitu $92,59 \%$ pada pertemuan pertama dan $100 \%$ pada pertemuan kedua, siswa antusias dengan materi yang diberikan yaitu $100 \%$ pada pertemuan pertama dan pertemuan kedua, siswa senang dengan gambar examples non examples yang digunakan yaitu $100 \%$ pada pertemuan pertama dan kedua, siswa berinteraksi dengan baik saat mengemukakan pendapat yaitu $66,66 \%$ pada pertemuan pertama dan $74,07 \%$ pada pertemuan kedua, siswa mencatat hal-hal penting yang dijelaskanpada buku catatannya yaitu $66,67 \%$ pada pertemua pertama dan $85,18 \%$ pada pertemuan kedua, siswa aktif bertanya dalam proses pembelajaran dengan metode examples non examples yaitu $59,25 \%$ pada pertemuan pertama dan $62,96 \%$ pada pertemuan kedua, siswa menjawab pertanyaan dengan baik yaitu $55,55 \%$ pada pertemuan pertama dan $66,66 \%$ pada pertemuan kedua, serta siswa dan gurumenyimpulkan pembelajaran yaitu $100 \%$ pada pertemuan pertama dan kedua. Hasil observasi siswa pada pertemuan pertama dengan rata-rata $80,08 \%$ dan pertemuan kedua dengan rata-rata $86,10 \%$.

Hasil rata-rata pertemuan pertama dan kedua yaitu $83,09 \%$ dan berada pada rentang $76 \%$ $100 \%$ yang berkriteria Baik, artinya dari pertemuan pertama dan kedua siswa telah mengikuti pembelajaran mulai dari pendahuluan sampai penutup pembelajaran dengan baik. Hasil observasi siswa lebih lanjut dapat dilihat pada Gambar 2.

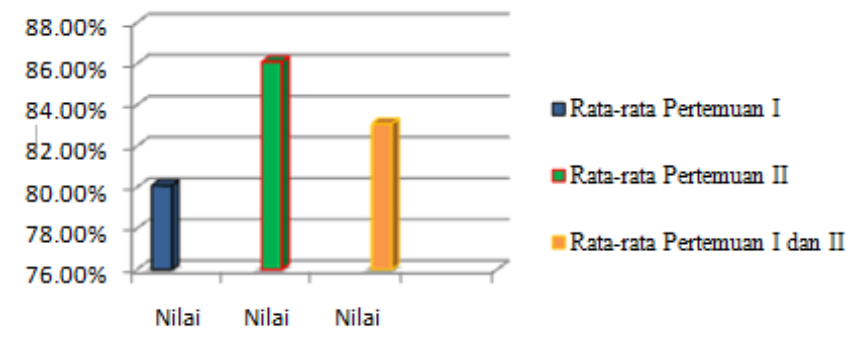

Gambar 2. Hasil Analisis Lembar Observasi Siswa

Sebelum sampel penelitian diberikan perlakuan, terlebih dahulu peneliti memberikan tes awal (pretest) kepada siswa kelas III Sekolah Dasar Negeri No.47 Sinar Kasih yang berjumlah 27 siswa untuk kelas IIIA sebagai kelas eksperimen dan 27 siswa kelas IIIB sebagai kelas kontrol. Tes 
awal (pretest) diperoleh nilai rata-rata 41,66 untuk kelas eksperimen dan 46,85 untuk kelas kontrol.

Analisis hasil Pretest menunjukkan bahwa tidak terdapat siswa yang memenuhi kriteria ketuntasan minimal (KKM) dengan nilai 65. Nilai rata-rata tes akhir (posttest) untuk kelas eksperimen yang diperoleh sebesar 77,59 dimana terdapat 22 siswa atau $81,48 \%$ siswa yang memenuhi kriteria ketuntasan minimal (KKM) sedangkan 5 siswa atau $18,52 \%$ siswa tidak memenuhi kriteria ketuntasan minimal (KKM). Rata-rata untuk kelas kontrol diperoleh 69,07 dimana terdapat 19 siswa atau $70,37 \%$ siswa yang memenuhi kriteria ketuntasan minimal (KKM) sedangkan 8 siswa atau $29,63 \%$ siswa tidak memenuhi kriteria ketuntasan minimal (KKM). Perbandingan hasil pretest dan pottest dapat dilihat pada Gambar 3.

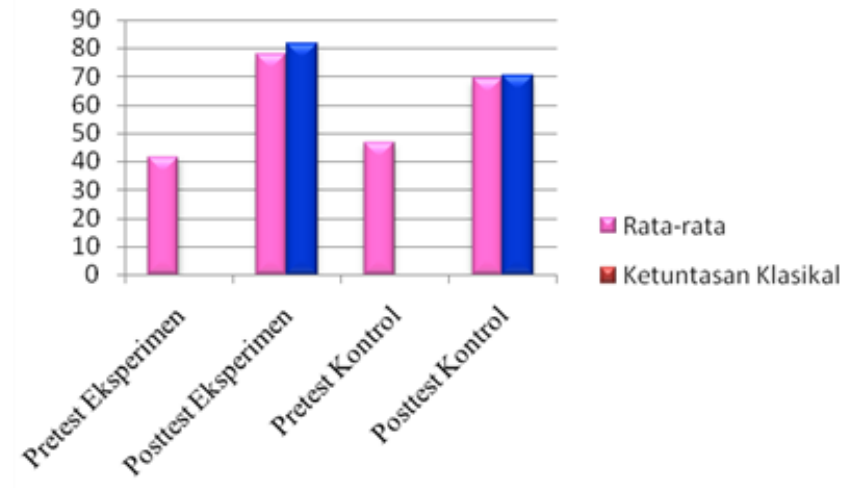

Gambar 3. Hasil Pretest dan Posttest

Hasil tes pada siswa kelas III Sekolah Dasar Negeri No 47 Sinar Kasih di kelas eksperimen mengalami kenaikan nilai dengan kategori tinggi. Artinya pembelajaran dengan menggunakan metode examples non examples dapat meningkatkan kemampuan kognitif siswa. Karena kedua data berdistribusi normal dan homogen, maka selanjutnya dilakukan uji parametrik. Sampel yang digunakan oleh peneliti sebanyak 27 siswa pada kelas eksperimen dan 27 siswa pada kelas kontrol, sehingga langkah selanjutnya menggunakan Uji t- dua sampel. Hasil uji t-dua sampel data pretest diketahui bahwa nilai $t_{\text {hitung }}$ adalah $-1,7$ sedangkan nilai $\mathrm{t}_{\text {tabel }}$ pada $\alpha=5 \%$ dengan $\mathrm{db}(\mathrm{N}+\mathrm{N}-2=52)$ adalah 2,011. Hal ini berarti nilai $\mathrm{t}_{\text {hitung }}<\mathrm{t}_{\text {tabel }}$ yaitu $-1,7<2,011$ maka Ho diterima, artinya tidak terdapat perbedaan yang signifikan kemampuan kognitif antara siswa kelas eksperimen dan siswa kelas kontrol sebelum pembelajaran.

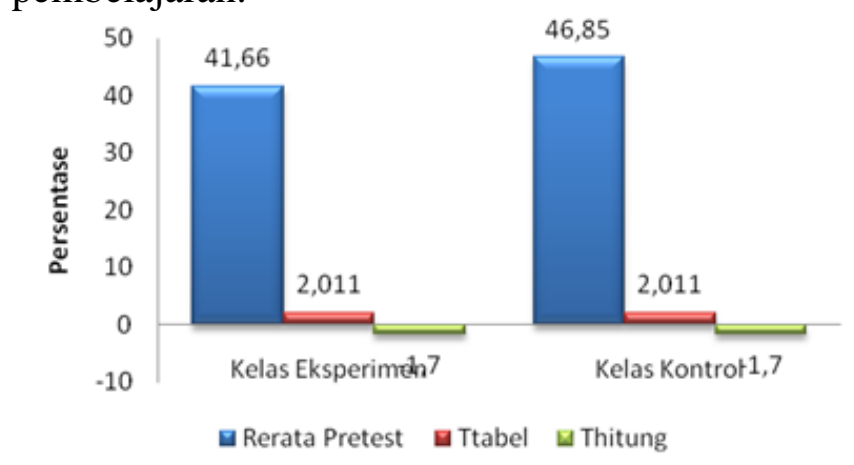

Gambar 4. Hasil Uji T untuk Data Pretest

Setelah data posttest dihitung secara statistik dengan diketahui bahwa nilai $t_{\text {hitung }}$ adalah 2,79 sedangkan nilai tabel pada $\alpha=5 \%$ dengan $\mathrm{db}$ $(\mathrm{N}+\mathrm{N}-2=52)$ adalah 2,011 . Hal ini berarti nilai $t_{\text {hitung }}>t_{\text {tabel }}$ yaitu 2,79 $>2,011$ maka Ha diterima Terdapat perbedaan yang signifikan kemampuan kognitif antara siswa kelas eksperimen dan siswa kelas kontrol setelah pembelajaran.

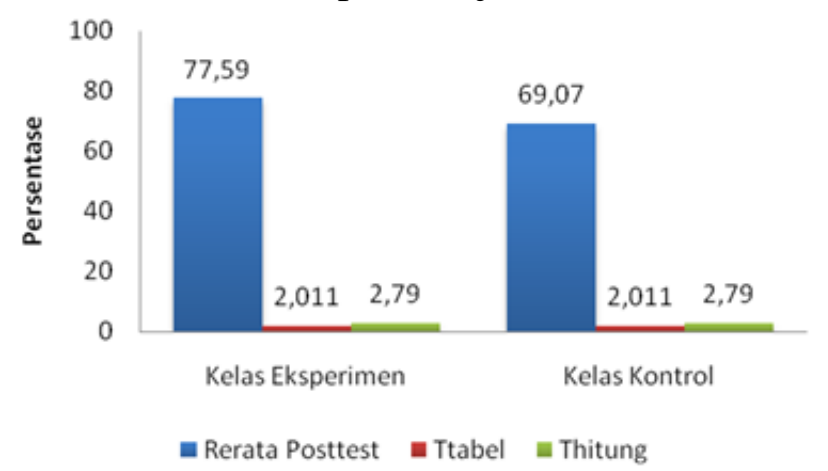

Gambar 5. Hasil Uji T untuk Data Posttest

Dari hasil perhitungan diperoleh rata-rata angket $88 \%$ berkriteria sangat kuat karena berada pada rentang $81 \%$ - 100\%. Dapat disimpulkan bahwa respon siswa setelah proses pembelajaran dengan menggunakan metode examples non examples bernilai positif, yang artinya siswa sangat tertarik dengan metode yang diterapkan. Hasil angket respon siswa lebih lanjut dapat dilihat pada Gambar 6. 


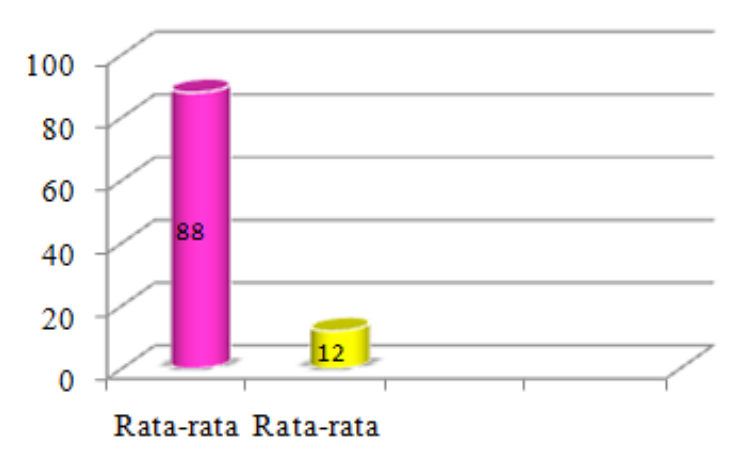

Gambar 6. Rata-rata Angket Respon Siswa

\section{KESIMPULAN DAN SARAN}

Berdasarkan penelitian, dapat ditarik kesimpulan "Terdapat pengaruh yang signifikan metode pembelajaran examples non examples terhadap kognitif siswa pada materi mengenal penggunaan uang sesuai dengan kebutuhan di kelas III Sekolah Dasar Negeri No.47 Sinar Kasih. Berdasarkan sub masalah penelitian, maka dapat disimpulkan hal-hal sebagai berikut. Aktivitas siswa dan guru saat menggunakan metode examples non examples pada meteri mengenal penggunaan uang sesuai dengan kebutuhan di kelas III Sekolah Dasar Negeri No.47 Sinar Kasih pada kelas eksperimen berjalan dengan baik. Dari hasil observasi guru pertemuan pertama dan kedua diperoleh persentase $100 \%$, artinya guru telah menyampaikan materi sesuai engan yang diharapkan. Aktivitas siswa pada pertemuan pertama $80,08 \%$ dan pertemuan kedua $86,10 \%$ dengan rata-rata pertemuan pertama dan kedua 83,09\% berkriteria Baik (B) karena berada pada rentang $76 \%$ - 100\%. Kognitif siswa saat pengukuran awal (pretest). Hasil belajar tes awal (pretest) diberikan sebelum menggunakan metode examples non examples pada materi mengenal penggunaan uang sesuai dengan kebutuhan dengan nilai rata-rata 41,66 pada kelas eksperimen dan di kelas kontrol sebelum mengunakan metode konvensional dengan nilai rata-rata 46,85. Kognitif siswa saat pengukuran akhir (posttest). Hasil belajar tes akhir (posttest) diberikan setelah diterapkan pembelajaran dengan metode examples non examples pada materi mengenal penggunaan uang sesuai dengan kebutuhan di kelas eksperimen dengan nilai rata-rata 77,59 dan setelah diterapkan pembelajaran konvensional pada materi mengenal penggunaan uang sesuai dengan kebutuhan di kelas kontrol dengan nilai rata rata 69,07. Kognitif siswa saat pengukuran awal (pretest). Hasil belajar tes awal(pretest) di kelas kontrol sebelum mengunakan metode konvensional pada materi mengenal pengguaan uang sesuai dengan kebutuhan dengan nilai rata-rata 46,85, dan pengukuran akhir (posttest) dengan nilai rata-rata 69,07. Kognitif siswa saat pengukuran awal (pretest). Hasil belajar tes awal (pretest) di kelas eksperimen sebelum mengunakan metode examples non examples pada materi mengenal pengguaan uang sesuai dengan kebutuhan dengan nilai rata-rata 41,66 dan pengukuran akhir (posttest) dengan nilai rata-rata 77,59. Dapat disimpulkan Pada hasil pretest diketahui bahwa nilai thitung adalah $-1,7$ sedangkan nilai $t_{\text {tabel }}$ pada $\alpha$ $=5 \%$ dengan $\mathrm{db}(\mathrm{N} 1+\mathrm{N} 2-2=52)$ adalah 2,011 . Hal ini berarti nilai $t_{\text {hitung }}<\mathrm{t}_{\text {tabel }}$ yaitu $-1,7<2,011$ maka Ho diterima yang artinya tidak terdapat perbedaan yang signifikan kemampuan kognitif siswa antara kelas eksperimen yang menggunakan metode pembelajaran examples non examples dengan kelas kontrol yang menggunakan metode pembelajaran konvensional pada materi mengenal penggunaan uang sesuai dengan kebutuhan. Pada hasil posttest diketahui bahwa nilai thitung adalah 2,79 sedangkan nilai tabel pada $\alpha=5 \%$ dengan $\mathrm{db}$ $(\mathrm{N} 1+\mathrm{N} 2-2=52)$ adalah 2,011. Hal ini berarti nilai $t_{\text {hitung }}>\mathrm{t}_{\text {tabel }}$ yaitu 2,79 $>2,011$ maka Ha diterima yang artinya terdapat perbedaan yang signifikan kemampuan kognitif siswa antara kelas eksperimen yang menggunakan metode pembelajaran examples non examples dengan kelas kontrol yang menggunakan metode pembelajaran konvensional pada materi mengenal penggunaan uang sesuai dengan kebutuhan. Respon siswa setelah proses pembelajaran menggunakan metode examples non examples pada materi mengenal penggunaan uang sesuai dengan kebutuhan di kelas III Sekolah Dasar Negeri No 47 Sinar Kasih dengan kategori sangat kuat, karena hasil analisis angket respon siswa rata-ratanya $88,15 \%$ dan berada pada rentang persentase $81 \%-100 \%$ sehingga respon siswa positif.

Berdasarkan perolehan data hasil penelitian yang didapatkan oleh peneliti, maka peneliti mengemukakan beberapa saran sehingga dapat 
memberikan beberapa manfaat bagi pembaca maupun peneliti sendiri, yaitu: Siswa diharapkan untuk selalu berperan aktif dalam proses pembelajaran seperti berani mengemukakan pendapat, tidak takut salah dan memiliki rasa ingin tahu. Dengan demikian, akan meningkatkan rasa percaya diri terhadap kemampuan yang telah dimiliki. Guru diharapkan memiliki empat kompetesi dasar yaitu kompetensi pedagogik, profesionalisme, kepribadian dan sosial, agar dapat masuk kedalam dunia anak yang memiliki karakter yang berbeda-beda sehingga dapat memberikan inovasi baru dalam proses pembelajaran. Guru diharapkan memiliki pengetahuan dan kemampuan yang cukup sehingga dapat memilih metode pembelajaran yang kondusif, tepat dan sesuai dengan materi yang disajikan dan mampu melibatkan keaktifan siswa dalam proses pembelajaran

\section{DAFTAR PUSTAKA}

[1] Sulo. La. L. S. dan Tirtarahardja. Umar. Pengantar Pendidikan. Jakarta: PT Rineka Cipta.

[2] Budiningsih. Asri. C. (2005). Belajar dan Pembelajaran. Jakarta: PT Rineka Cipta.

[3] Ngalimun. (2013). Strategi dan Model Pembelajaran. Yogyakarta: Aswaja Pressindo

[4] Sugiyono. (2013). Metode Penelitian Pendidikan Pendekatan Kuantiatif,dan R\&D. Bandung : PT Alfabeta

[5] Sugiyono. (2011). Metode Penelitian Kuantitatif Kualitatif dan RD. Bandung: PT Alfabeta. 